\title{
Influence of supplemented animal fats upon digestibility of ration components by ruminants
}

\author{
N. D. Dijkstra
}

Institute for Livestock Feeding and Nutrition Research 'Hoorn', Hoorn, The Netherlands

Received 25 July, 1968

\section{Summary}

In this paper the results are given of four digestion experiments with wethers. The first experiment involves five digestion trials with meal of artificially dried lucerne, to which successively $0,5,10,15$ and $20 \%$ of animal fat was added. In the second experiment $10 \%$ of linseed oil or emulgated linseed oil was added to a hay ration. There was no difference in effect on the digestibility between linseed oil and emulgated linseed oil. In the third and fourth experiment the daily ration of the wethers consisted of $500 \mathrm{~g}$ of hay and $600 \mathrm{~g}$ of a concentrate mixture, to which successively $0,5,10,15$ and $20 \%$ of lard was added. In all experiments the digestion coefficients of crude protein, $\mathrm{N}$-free extract and especially crude fibre decreased in consequence of the fat addition.

In experiment 1 , in which the daily ration consisted of lucerne meal, which is rich in $\mathrm{Ca}$, there was no decrease in digestibility, when 5 or $10 \%$ of fat was added; these decreases only began with a supplement of more than $10 \%$ fat. A theory is developed by which this result can be explained.

Finally, in experiment 1,3 and 4 the nutritive value of the total rations with the different percentages of fat were calculated. The starch equivalents were calculated with two different factors for supplemented fat, e.g. 2.41 in accordance with Kellner and 3.0, following the advice of the C.V.B. (Dutch Central Feeding Board).

\section{Introduction}

In the Netherlands, just as in many other countries, the surplus of animal fats increases regularly during the last years. The cause of this must especially be sought in the development of synthetic detergents - by which the demand of the soapworks for animal fat continually decreases - and in the shifting in human nutrition from animal fats to vegetable fats. Consequently it is a necessity to look for new sales potentials of animal fats.

One of the most plausible solutions of this problem should be to use these fats in concentrates for livestock. However, most of the available fats have a too high iodine value for rations for porkers, so that the supplemented fat has mostly a harmfull influence on the hardness of the pork. This disadvantage does not count by working up these fats in concentrate-mixtures for ruminants. The problematic of using fat in the nutrition of ruminants and especially of milking cows is not new. In 
numerous publications attention is paid to the question of the significance, the utilization and the effect of fat in the rations of ruminants. The results of the several investigations are not always the same, often even contradictory, which demonstrates how difficult these problems are.

In this paper we will not go into the influence of different fats in the ration upon the milk yield of dairy cows, neither into the influence of these fats upon the microflora of the rumen. Here I should like to confine myself to refer to a recent publication of Orth et al. (1966) about these subjects. In this paper I will only report something about the influence of supplemented fats upon the digestibility by ruminants.

\section{Literature}

There are in literature many reports about the effect of such fats on the digestibility of rationcomponents. So reported Swift et al. (1947), Brooks et al. (1954), Ward et al. (1957), Dyer et al. (1957), Brethour et al. (1958), Page et al. (1958) and Davidson and Woods (1960) about the depressing effect of supplemented fats on the digestibility of the different components of the rations and especially of crude fibre. These results are not in agreement with those of others. Esplin et al. (1963) reported that the addition of $4 \%$ tallow or $4 \%$ hydrolyzed vegetable or animal fat to a fattening ration improved the digestibility of crude protein and crude fibre, though the increases were not significant. Also Francke (1958) and Iwema (1967) found that an addition of $5 \%$ fat does not have any influence on the digestibility. Nottle and Rook (1963) added to a basal diet for cows linseed oil, cod liver oil or beef tallow. The supplement of linseed oil had no effect at all. The cod liver oil caused a fall in acetic acid and an increase in propionic acid in the rumen, whereas tallow tended to give reverse changes. There was only a slight decrease in the digestibility of crude fibre and of fat-free dry matter in the case of the tallow addition. Esplin et al. (1963) wonder if perhaps a lower roughage level of the rations has led to these contradictory results.

Van Es and Gaillard (1967) suppose that the percentage of supplemented fat plays an important part. They think that the figure 2.41, found by Kellner for the starch equivalent of $1 \mathrm{~g}$ dig. crude fat in oil seeds and its byproducts, is too low as a result of his experimental technics. To obtain in his respiration experiments well reproducible results Kellner has to add to his basal ration $15 \%$ of fat.

Nehring and his co-workers, who get near to this problem in quite an other way, could operate with smaller amounts of fat and moreover not with supplemented fat, but with fat already present in the concentrates. So they found a factor of about 3.5 for the starch equivalent of $1 \mathrm{~g}$ dig. fat (Schiemann et al., 1963; Nehring et al., 1966).

Van Es and Gaillard conclude that the large amount of fat in Kellner's experiments must have decreased the digestibility of the total ration, what results in the too low factor 2.41 in comparison with the factor 3.5. Consequently, the addition of a high percentage of fat involves a decrease in digestibility of organic matter, whereas, on the other hand, an addition of a small amount of fat (e.g. $5 \%$ ) will not have any influence on the digestibility.

Brooks et al. (1954) and Pfander and Verma (1957) suggested the coating of the feed particles with fat is one of the reasons for the decrease of digestibility. Brooks et al. (1954) and Ward et al. (1957) reported that the presence of lucern ash and White 
et al. (1958) that an excess of calcium in sheep rations alleviated the depressing effect of supplemental fat on cellulose and protein digestibility. Tillman and Brethour (1958) reported that corn oil reduced the apparent and true digestibility of calcium which resulted in a decreased calcium retention. White et al. suggested that it may be possible to explain the calcium-fat relationship as due to the excretion of calcium soaps. Niesar (1965) attributes the digestion depression especially to the percentage of unsaturated fatty acids in supplemented fat.

A comparison of the ratio unsaturated to saturated fatty acids between the rations and the rumen contents shows that here is a fatty acids hydrogenation by the microflora of the rumen. Niesar supposes that unsaturated fatty acids hamper a normal growth of the rumen bacteria and -protozoa and that the microflora tries to get rid of these unsaturated acids by hydrogenation. Consequently, the greatest depressing effect on digestibility will be found by adding oils, but because the addition of beef tallow and lard produces already a fair decrease too, a content of 40-50\% of unsaturated fatty acids in the fat is already too high for the microflora of the rumen. Niesar suggests that the rumen microbial activity is maximal if the amount of supplemented fat is minimal. When it is, for energetic reasons, desirable to add fats to concentrate rations of full-grown ruminants, he supposes that it is necessary to adapt the kind of fat to the demands of the microflora of the rumen.

This short review of literature, that does not claim to be complete, in my opinion, shows clearly that there is among other things still a need of trials to decide how much the digestibility of the components of a ration decreases by adding different percentages of fat.

\section{Experimental procedures and results}

Almost all digestibility trials were carried out in triplicate using Texel wether sheep (Fig. 1); only experiment 2 was carried out in duplicate.

\section{1st Experiment}

This experiment involves five digestibility trials with meal of artificially dried lucerne, to which respectively $0,5,10,15$ and $20 \%$ animal fat was added. For this purpose we used two rations, viz.:

lucernemeal $A$ : lucernemeal without fat,

lucernemeal B: the same lucernemeal mixed up with $20 \%$ steamed destructorfat, stabilized with $0.06 \%$ anthox 8 .

In the 1 st trial each of the three wethers received daily $1200 \mathrm{~g}$ of lucernemeal $\mathrm{A}$; in the 2nd $900 \mathrm{~g}$ lucernemeal $\mathrm{A}+300 \mathrm{~g}$ lucernemeal $\mathrm{B}$; in the $3 \mathrm{rd} 600 \mathrm{~g}$ lucernemeal $\mathrm{A}+600 \mathrm{~g}$ lucernemeal $\mathrm{B}$; in the 4 th $300 \mathrm{~g}$ lucernemeal $\mathrm{A}+900 \mathrm{~g}$ lucernemeal $\mathrm{B}$ and in the 5th $1200 \mathrm{~g}$ of lucernemeal B. In this way we obtained the composition of the rations, mentioned in Table 1. This table shows that the fat is determined in two different ways. Wind et al. (1966) pose that the determination of crude fat in feed and faeces by direct extraction with ether does not give right digestion coefficients, because an important fraction of the lipids, especially in faeces, is not extracted in this way. By the presence of calcium and magnesium in the food a part of the fatty acids is excreted as unsoluble $\mathrm{Ca}$ and $\mathrm{Mg}$ soaps (Cheng et al., 1949; Petterson, 1964). Consequently only a part of the excreted fatty acids is determined by etherextraction and thus the digestion coefficients of crude fat are too high. 

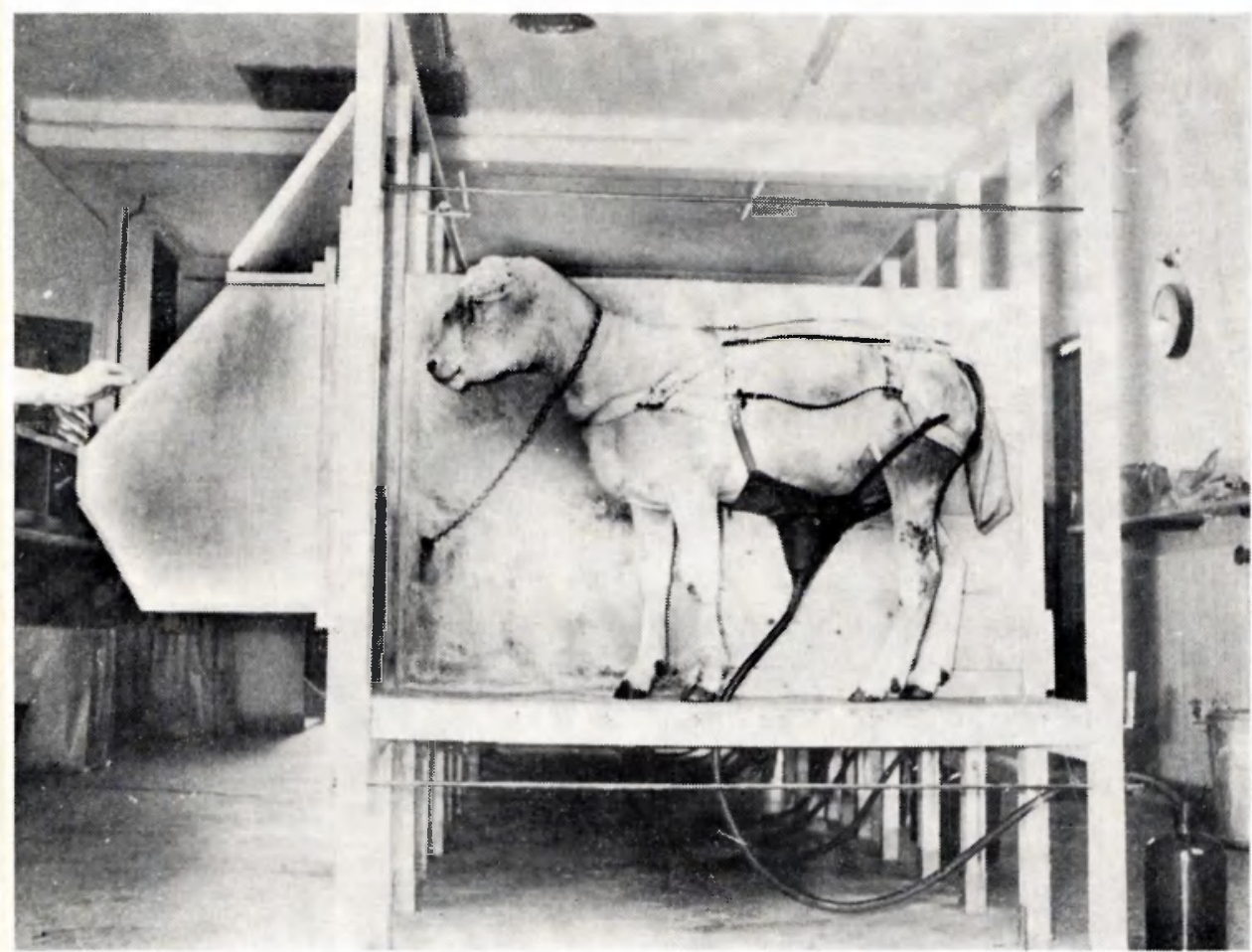

Fig. 1 Digestibility trial with a Texel wether sheep

In method 2 fat is determined by extraction with tetra after boiling with $\mathrm{HCl}$. In this way we get more exact values for digestible fat, but, alas, till now this fat extraction method is not often used in fundamental research work about nutritive value of the different feedingstuffs. The average values of the digestion coefficients are presented in Table 2. This table demonstrates the great differences we can get when method 1 or method 2 for fatextraction is used. By extraction feed and faeces by ether the digestion coefficient of fat increases from 53 in exclusive lucernemeal via $82,87,89$ till 90 for lucernemeal with $20 \%$ fat. By extraction with $\mathrm{CCl}_{4}$ after boiling feed and faeces with $\mathrm{HCl}$ the digestion coefficient of fat increases only from 48 till 70 . When a great part of the fatty acids in the faeces is not determined as fat, then it will be calculated as $\mathrm{N}$-free extract and consequently, in the case of fatextraction by ether the digestion coefficients of $\mathrm{N}$-free extract will be lower and by adding high percentages of fat even much lower.

When we consider the figures obtained by using method 2 as the most exact ones, we see that by increasing percentages of supplemented fat from 0 to $20 \%$ the digestion coefficient of crude protein decreases from 64 to 58 , that of $\mathrm{N}$-free extract from 75 to 71 and that of crude fibre from 58 to 46 . In this experiment these decreases only began, when more than $10 \%$ of fat was added. Table 3 demonstrates the influence of the supplemented fat on the nutritive value. The dig. crude protein percentage decreases from 12.3 to $8.9 \%$, while the starch equivalent (S.E.) increases 


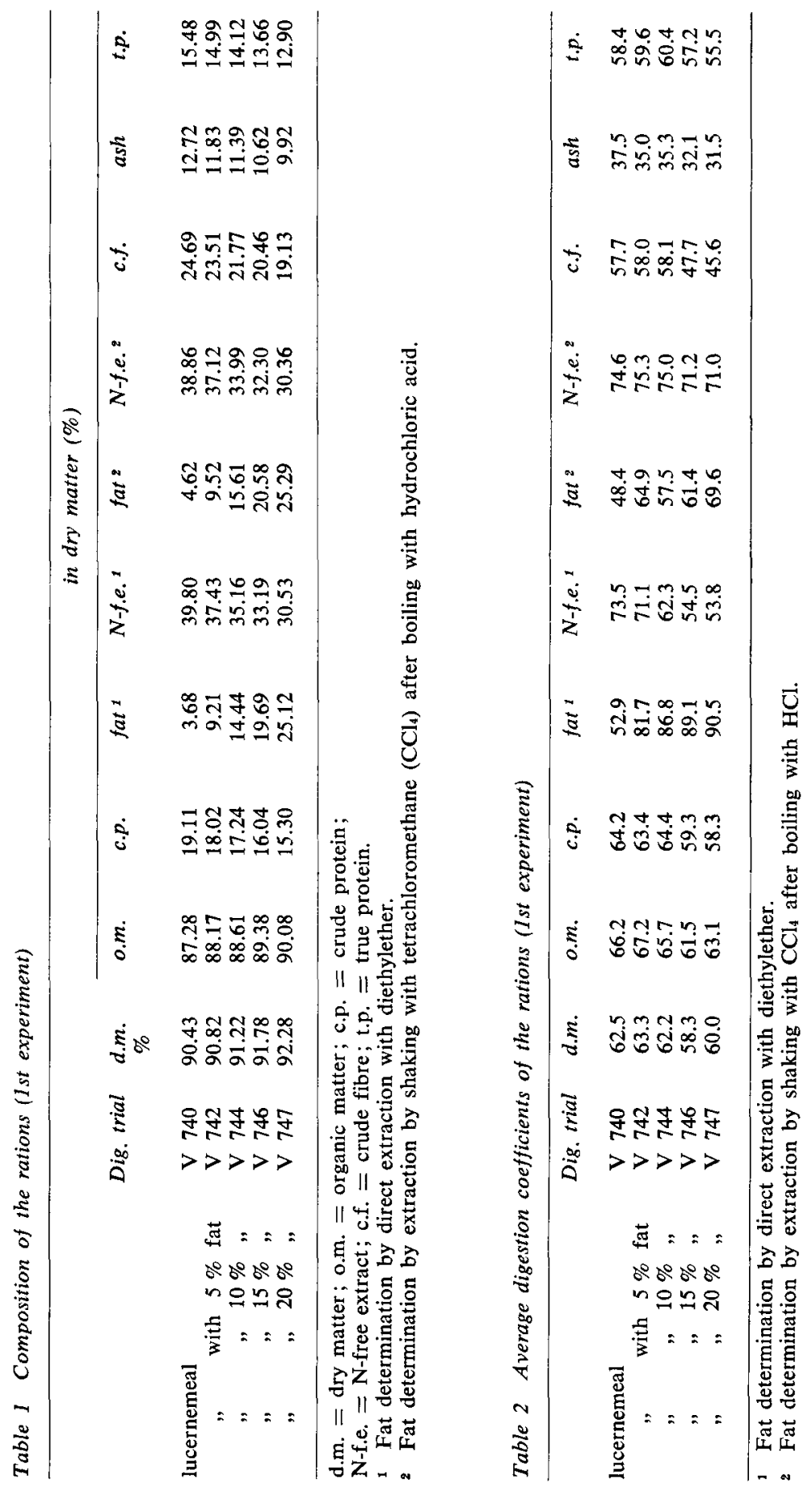


Table 3 Nutritive value of the dry matter of the rations (1st experiment)

\begin{tabular}{|c|c|c|c|c|}
\hline \multirow{2}{*}{\multicolumn{2}{|c|}{ lucernemeal }} & $\begin{array}{c}\text { dig. c.p. } \\
(\%)\end{array}$ & $\begin{array}{c}\text { S.E. } \\
\text { calculated with } \\
\text { Kellner's } \\
\text { fatfactors }\end{array}$ & $\begin{array}{l}\text { S.E. } \\
\text { calculated with } \\
\text { the factor } 3.0 \\
\text { for supple- } \\
\text { mented fat }\end{array}$ \\
\hline & & 12.27 & 45.1 & 45.1 \\
\hline , & with $5 \%$ fat & 11.42 & 53.4 & 55.7 \\
\hline$"$ &, $10 \%$ & 11.10 & 57.1 & 61.1 \\
\hline$"$ & $" 15 \% "$ & 9.51 & 60.4 & 66.6 \\
\hline$"$ & " $20 \%$, & 8.92 & 69.9 & 79.0 \\
\hline
\end{tabular}

from 45 to 70 . When we follow the advice of a committee of the C.V.B. (De Jong, 1968) and use for supplemented fat the factor 3.0 instead of 2.41 , the starch equivalent increases from 45 to 79 . In these calculations we have used the fatpercentages and -digestion coefficients determined by the second extraction method.

\section{2nd Experiment}

In 1965 one of my co-workers in this Institute studied the influence of addition of linseed oil and emulgated linseed oil to a ration of grasshay on the activity of the rumenflora. In this experiment he used 2 fistulated wethers. The digestibility of this hay was determined in a preceding experiment (V 762) with 3 other wethers. In trial V 763 both wethers received daily $1200 \mathrm{~g}$ of hay, which was given in two times (about the half at 8.30 a.m. and the other half at 5.00 p.m.). Each time $65 \mathrm{ml}$ linseed oil was added to the hay. Consequently, each of them received daily $130 \mathrm{ml}$ $=120.9 \mathrm{~g}$ of linseed oil, what is approximately $10 \%$ of the daily hay ration. In trial V 764 instead of $130 \mathrm{ml}$ linseed oil $260 \mathrm{ml}$ emulgated linseed oil $(50 \%$ of oil and $50 \%$ of water) was added. In these experiments fistulated sheep were used to be able to take samples of the rumen content at the end of the digestion trial. However, in the scheme of these experiments we will only mention the results of the digestion trials (Table 4). This table shows firstly that there was an important difference in the digestion coefficients between both animals and secondly that there was practically no difference in digestibility between the addition of linseed oil and emulgated linseed oil. Consequently, we have averaged for each wether the digestion coefficients obtained by addition of linseed oil and emulgated linseed oil.

The results with wether 63 show that the addition of oil to the hayration has decreased the digestion coefficient of $\mathrm{N}$-free extract from 73 to 70 and that of crude fibre from 76 to 69 , whereas there was practically no decrease in the digestibility of the crude protein. The digestion coefficients obtained with wether 262 are much lower. According to these results the digestion coefficient of $\mathrm{N}$-free extract was decreased to 66 , that of crude fibre to 61 , that of crude protein from 60 to 57 and that of organic matter from 71 to 64 . Unfortunately, we don't know the digestion coefficients of these two wethers on a hayration without supplemented oil.

\section{3rd' Experiment}

In each of the digestion trials in this experiment we used the same three wethers, viz. $N, O$ and $P$. In the first experiment ( $V$ 766) we determined the digestibility of a certain lot of grasshay. In the following trials the daily ration of each of the 


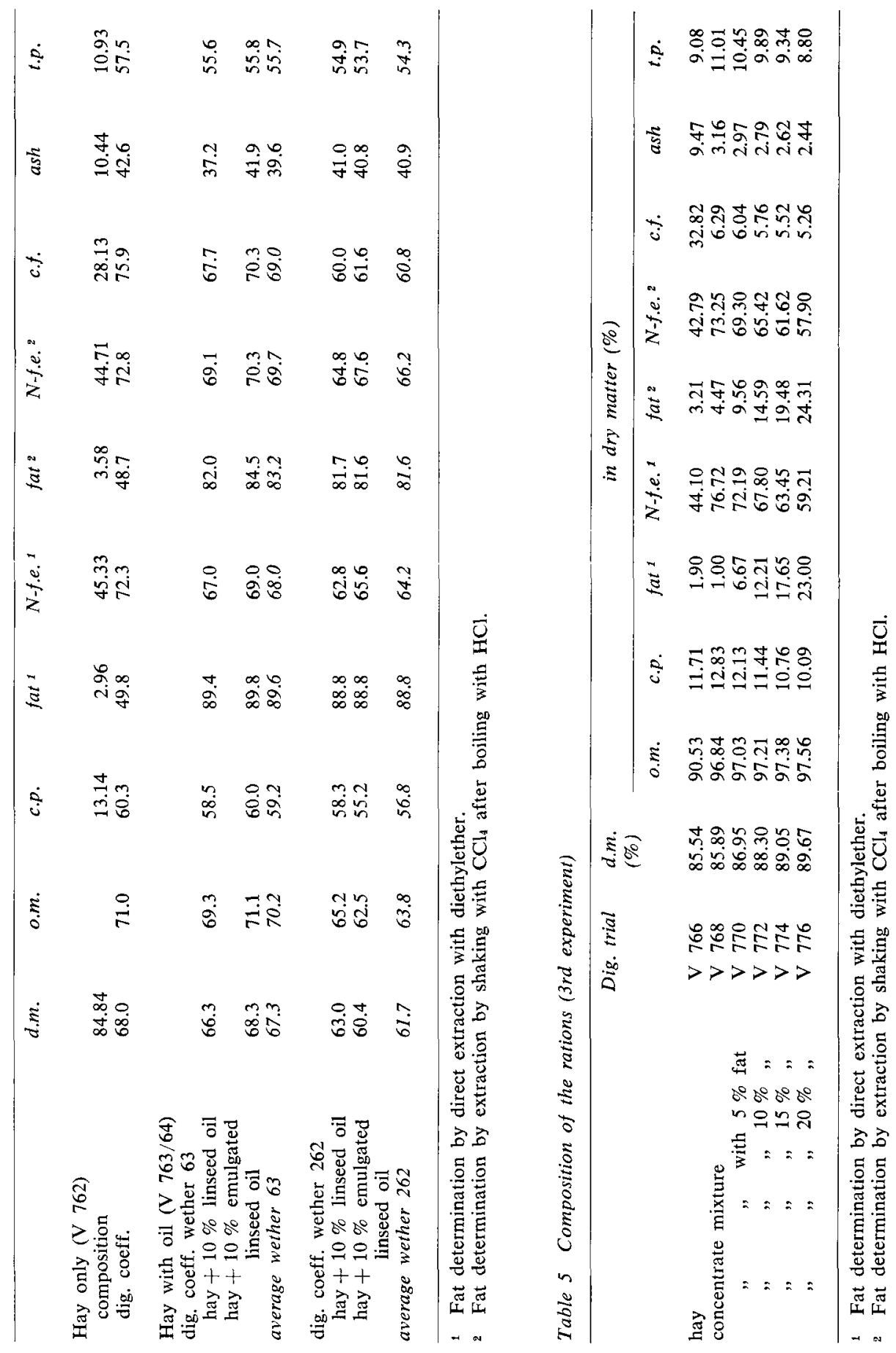


wethers consisted of $500 \mathrm{~g}$ of this hay and $600 \mathrm{~g}$ concentrate mixture, to which respectively $0,5,10,15$ and $20 \%$ of lard was added. For this purpose we used two concentrate mixtures, viz.:

mixture A: 1 part maize bran, 2 parts maize meal and 2 parts barley meal without fat,

mixture B: the same components mixed up with $20 \%$ lard, using $0.01 \%$ butylhydroxytoluene as antioxidant.

In the first trial with concentrates the hay ration of $500 \mathrm{~g}$ was supplemented with $600 \mathrm{~g}$ of mixture $\mathrm{A}$; in the following trials mixture A was successively replaced by mixture $\mathrm{B}$. In this way we obtained the composition of the concentrate mixtures mentioned in Table 5. The fatcontent regularly increases from $4.47 \%$ to $24.31 \%$ and consequently all the other components of the dry matter decrease. In Table 6 the average digestion coefficients of the total rations are given. The digestion coefficient of fat in the hayconcentrate ration increases from 59 to 75 . The digestion coefficients of all other components decrease, that of crude protein from 54 to 48 , that of $\mathrm{N}$-free extract from 79 to 76 and that of crude fibre from 57 to 46 . These decreases were somewhat irregular, for example the lowest digestion coefficients were found with $10 \%$ of fat in the concentrate mixture.

Table 7 shows the influence of the fat addition on the nutritive value. The dig. crude protein content of the hay-concentrate mixture decreases from 6.7 to $5.2 \%$. By using Kellner's fatfactors the starch equivalent increases from 57 to 66 and by using the factor 3.0 for supplemented fat it increases from 57 to 71 .

\section{4th Experiment}

Because the results of the 3 rd experiment were irregular this experiment was repeated the next year with the same wethers. We used other hay and other concentrate mixtures, viz.:

mixture A : $40 \%$ maize meal, $40 \%$ barley meal and $20 \%$ wheat bran,

mixture B : the same components mixed up with $20 \%$ lard, using $0.01 \%$ anthrancine as antioxydant.

Just as in the preceding experiment we started with a digestion trial with hay only, the second was with $500 \mathrm{~g}$ hay and $600 \mathrm{~g}$ of concentrate mixture A. In the following trials mixture $\mathrm{A}$ was successively replaced by mixture B. So we obtained the composition of the concentrate mixtures, given in Table 8 . The fatcontent increases regularly from 3.20 to $23.66 \%$ and simultaneously all the other components decrease. The average digestion coefficients of the total rations are gathered in Table 9 . The

Table 7 Nutritive value of the dry matter of the rations (3rd experiment)

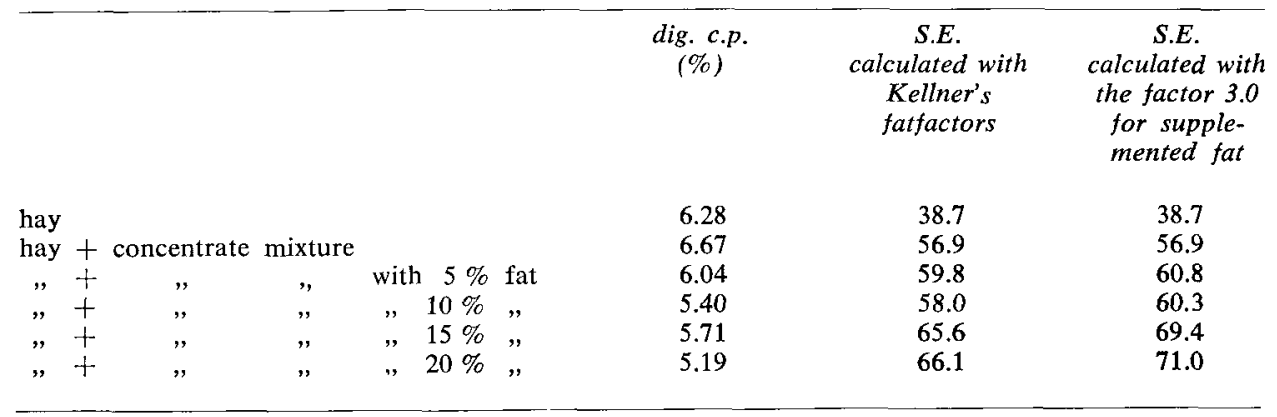



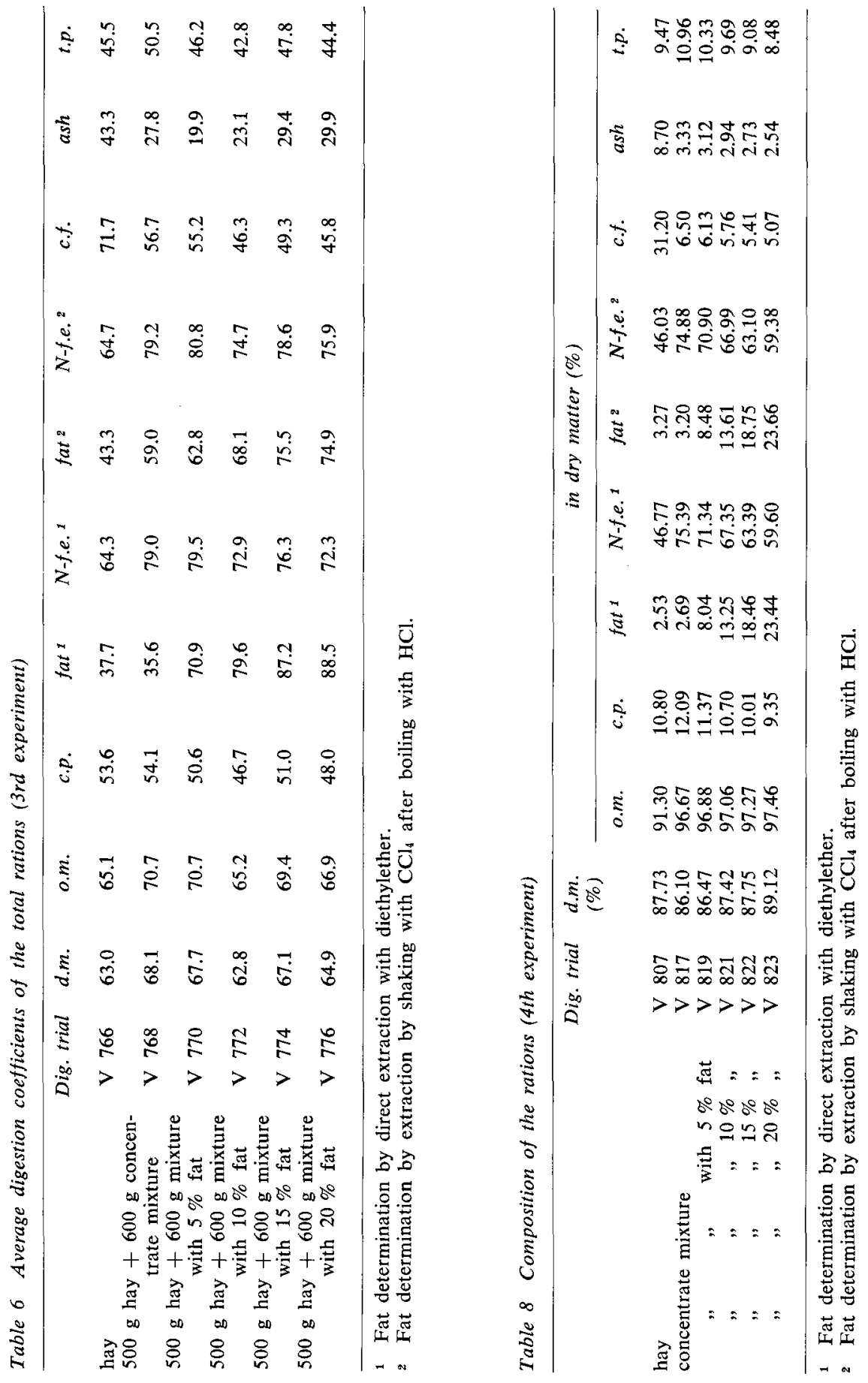
N. D. DIJKSTRA

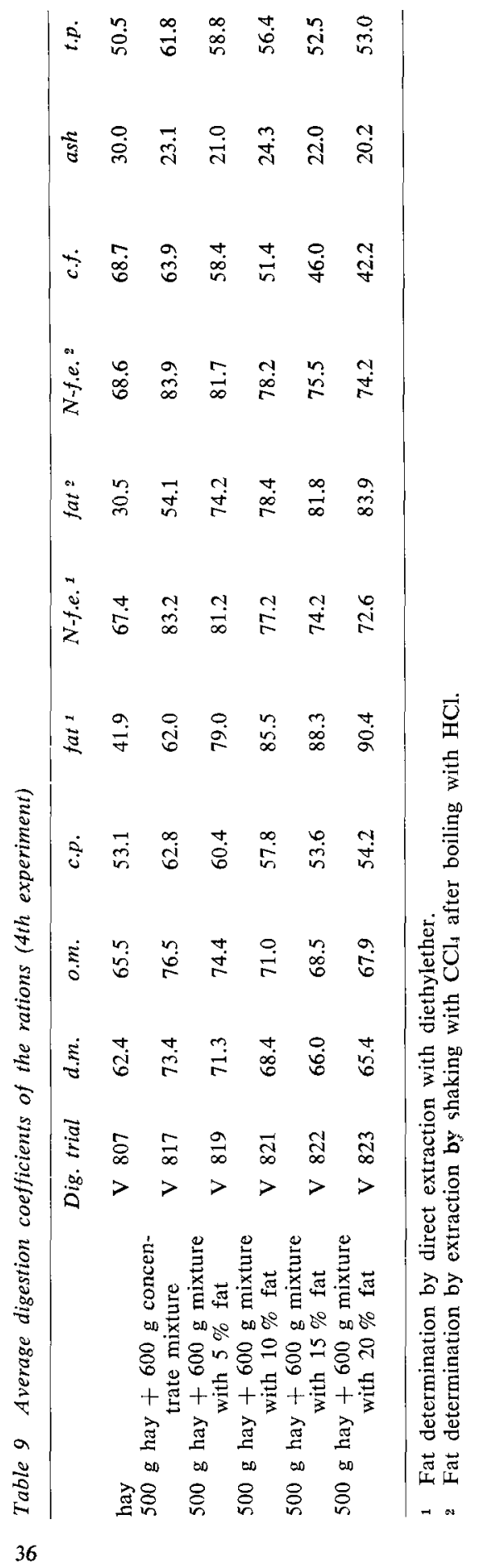


Table 10 Nutritive value of the dry matter of the rations (4th experiment)

\begin{tabular}{|c|c|c|c|c|c|c|c|}
\hline & & & & & $\begin{array}{c}\text { dig. c.p. } \\
(\%)\end{array}$ & $\begin{array}{c}\text { S.E. } \\
\text { calculated with } \\
\text { Kellner's } \\
\text { fatfactors }\end{array}$ & $\begin{array}{l}\text { S.E. } \\
\text { calculated with } \\
\text { the factor } 3.0 \\
\text { for supple- } \\
\text { mented fat }\end{array}$ \\
\hline \multicolumn{5}{|l|}{ hay } & 5.73 & 41.3 & 41.3 \\
\hline \multicolumn{5}{|c|}{ hay + concentrate mixture } & 7.22 & 61.7 & 61.7 \\
\hline$"+$ & , & ," & with $5 \%$ & fat & 6.71 & 63.5 & 64.8 \\
\hline , + & $"$ & , &, $10 \%$ &, & 6.21 & 63.8 & 66.5 \\
\hline , & $"$ & " & $" 15 \%$ & , & 5.56 & 65.2 & 69.4 \\
\hline$"+$ & , & , &, $20 \%$ & , & 5.42 & 68.4 & 73.9 \\
\hline
\end{tabular}

digestion coefficient of fat in the hay-concentrate ration increases from 54 to 84 . The digestion coefficients of all other components decrease, that of crude protein from 63 to 54 , that of $\mathrm{N}$-free extract from 84 to 74 and that of crude fibre from 64 to 42 . In this experiment these decreases were regular.

The influence of the fat addition upon the nutritive value is given in Table 10. The dig. crude protein content of the total ration decreases from 7.2 to $5.4 \%$. The starch equivalent with the fatfactor 2.41 increases from 62 to 68 and with the fatfactor 3.0 from 62 to 74 .

\section{Discussion}

In all experiments the fat in food and faeces was determined in two different ways, viz.:

a. by direct extraction with ether,

b. by extraction with tetra after boiling with $\mathrm{HCl}$.

In each of the experiments we found in the rations to which fat or oil were added, a higher digestion coefficient for fat, determined by method (a), as for fat, determined by (b). This is due to a much higher fatcontent in the faeces by method (b). The average daily quantities of fat in the faeces in each of the experiments - determined in the two different ways - are mentioned in Table 11. The difference between both values will probably be mainly $\mathrm{Ca}$ - and $\mathrm{Mg}$-soaps in the faeces, which are unsoluble in ether. In the 3rd and 4th experiment with hay + concentrates the difference increased gradually with the percentage of supplemented fat. In the first experiment, the difference increased quickly till a very high value and with $10 \%$ of supplemented fat this value had already almost reached its maximum level. The further increase was only small.

In this first experiment lucernemeal was fed, which is rich in $\mathrm{Ca}$. In the ration with $10 \%$ supplemented fat each wether received in this experiment daily $10.7 \mathrm{~g} \mathrm{Ca}$ and $2.3 \mathrm{~g} \mathrm{Mg}$. In experiment 3 the daily ration with $10 \%$ fat contained only $3.2 \mathrm{~g} \mathrm{Ca}$ and $1.8 \mathrm{~g} \mathrm{Mg}$ and in experiment 4 only $2.8 \mathrm{~g} \mathrm{Ca}$ and $1.5 \mathrm{~g} \mathrm{Mg}$.

When we realize that $1 \mathrm{~g}$ Ca can combine itself theoretically with about $12-13 \mathrm{~g}$ palmitic and stearic acid and $1 \mathrm{~g} \mathrm{Mg}$ even with $20-22 \mathrm{~g}$, then it is obvious that when the daily ration contains a high Ca-percentage a considerable part of the fatty 
Table 11 Average daily quantities of fat $(g)$ in the faeces in each of the experiments

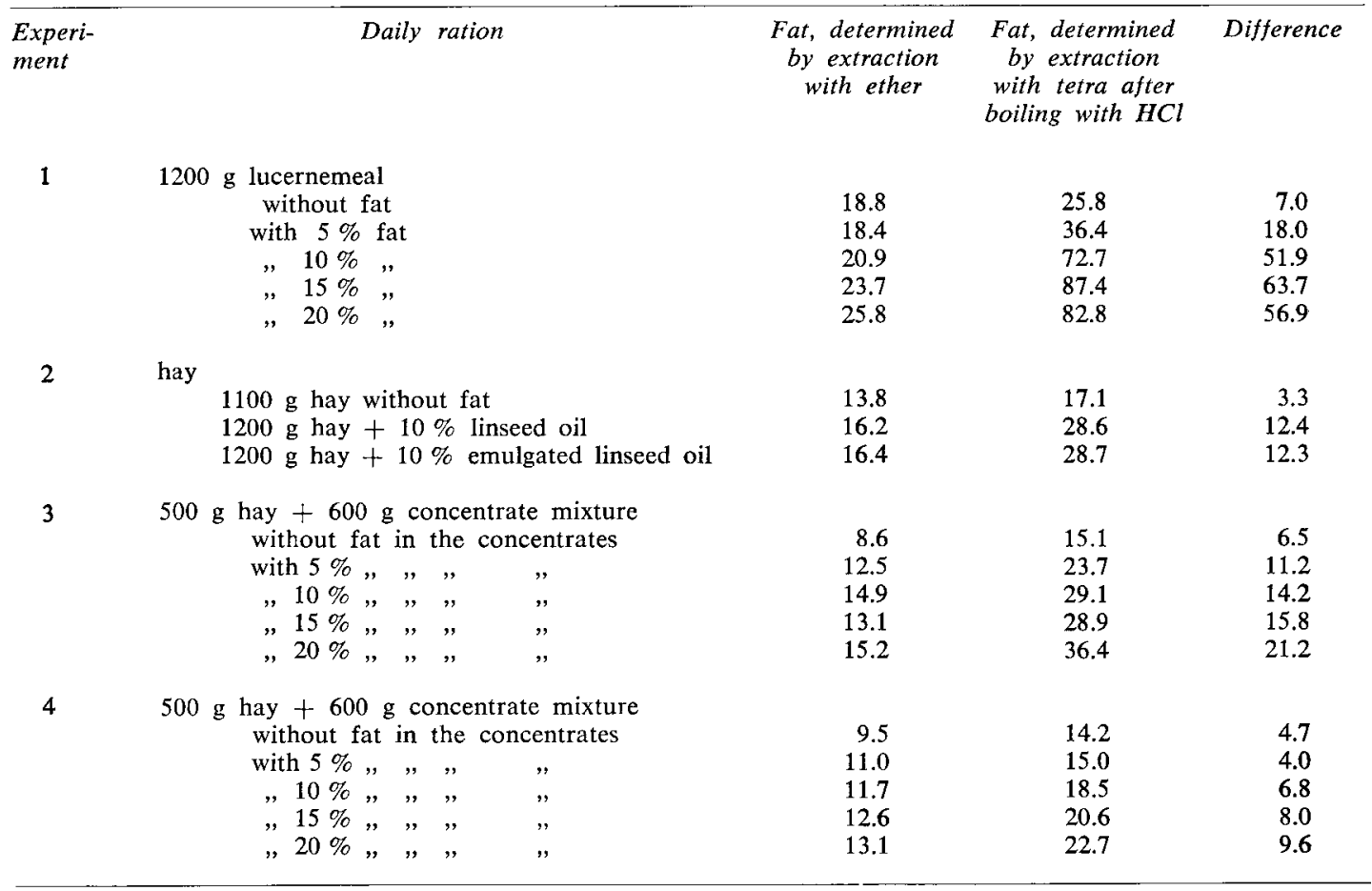

acids from the supplemented fat can be quickly taken away as unsoluble Ca-soaps. Consequently, the digestion coefficients of fat in such rations will be lower than in rations containing only a small amount of $\mathrm{Ca}$. When we suppose that already in the rumen these unsoluble compounds are formed, it is possible, that in the first experiment the amount of free fat in the rumen was much lower than the amount of fat, which was added. This can explain the fact that in the first experiment, as contrasted with the other experiments, the addition of $10 \%$ fat has not effected into a decrease in digestibility of the other components of the ration. Because an important fraction of the lipids, especially in faeces, is not extracted by the direct ether extraction, this method does not give right digestion coefficients for fat. In method (b) the fatty acids in the soaps are set free and are then extracted and so this method gives more exact values for digestible fat and also for dig. $\mathrm{N}$-free extract. Consequently, we have used in the calculations of this paper finally the percentages and digestion coefficients of fat, determined by last mentioned extraction method. The results of the digestion trials in experiment 1,3 and 4 are summarized in Table 12 . In all experiments the digestion coefficients of crude protein, $\mathrm{N}$-free extract and especially crude fibre decreased in consequence of the fat addition. The results of experiment 4 show that the irregularity in the digestibility-decrease in experiment 3 was only a coincidence. 
INFLUENCE OF SUPPLEMENTED ANIMAL FATS UPON DIGESTIBILITY

Table 12 Digestion coefficients

\begin{tabular}{|c|c|c|c|c|c|c|c|c|c|c|c|c|}
\hline \multirow{2}{*}{$\begin{array}{c}\% \\
\text { added } \\
\text { fat }\end{array}$} & \multicolumn{4}{|c|}{ Experiment 1} & \multicolumn{4}{|c|}{ Experiment 3} & \multicolumn{4}{|c|}{ Experiment 4} \\
\hline & c.p. & fat & $N$-f.e. & $c . f$. & c.p. & fat & $N$-f.e. & c.f. & c.p. & fat & N-f.e. & c.f. \\
\hline 0 & 64.2 & 48.4 & 74.6 & 57.7 & 54.1 & 59.0 & 79.2 & 56.7 & 62.8 & 54.1 & 83.9 & 63.9 \\
\hline 5 & 63.4 & 64.9 & 75.3 & 58.0 & 50.6 & 62.8 & 80.8 & 55.2 & 60.4 & 74.2 & 81.7 & 58.4 \\
\hline 10 & 64.4 & 57.5 & 75.0 & 58.1 & 46.7 & 68.1 & 74.7 & 46.3 & 57.8 & 78.4 & 78.2 & 51.4 \\
\hline 15 & 59.3 & 61.4 & 71.2 & 47.7 & 51.0 & 75.5 & 78.6 & 49.3 & 53.6 & 81.8 & 75.5 & 46.0 \\
\hline 20 & 58.3 & 69.6 & 71.0 & 45.6 & 48.0 & 74.9 & 75.9 & 45.8 & 54.2 & 83.9 & 74.2 & 42.2 \\
\hline
\end{tabular}

\section{Conclusions}

With increasing percentages of supplemented fat to a ration poor in $\mathrm{Ca}$ and $\mathrm{Mg}$ the digestibility of crude protein, $\mathrm{N}$-free extract and especially crude fibre decreases gradually.

In a ration rich in $\mathrm{Ca}$ and $\mathrm{Mg}$ a part of the supplemented fat is made already inactive by the forming of unsoluble soaps in the rumen. By this there is a lower decrease in digestibility of the different components, but, on the other hand, by a lower digestion coefficient of the fat there is also a smaller increase in starch equivalent of the ration.

\section{References}

Brethour, J. R., Sirny, R. J. \& Tillman, A. D., 1958. Further studies concerning the effects of fats in sheep rations. J. Animal Sci., 17: 171 .

Brooks, C. C., Garner, G. B., Gehrke, C. W., Muhrer, M. E. \& Pfander, W. H., 1954. The effect of added fat on the digestion of cellulose and protein by ovine rumen microorganisms. J. Animal Sci., $13: 758$.

Cheng, A. L. S., Morehouse, M. G. \& Deuel, H. J., 1949. The effect of the level of the dietary calcium and magnesium on the digestibility of fatty acids, simple triglycerides and some natural and hydrogenated fats. J. Nutr., $37: 237$.

Davidson, K. L. \& Woods, W., 1960. Influence of fatty acids upon digestibility of ration components by lambs and upon cellulose digestion in vitro. J. Animal Sci., 19: 54.

Dyer, I. A., Ensminger, M. E. \& Bleu, R. L., 1957. Effects of fat, oxytetracycline and stilbestrol on performance and hepatic stores of carotene and vitamin $\mathrm{A}$ in steers. J. Animal Sci., 16:828.

Es, A. J. H. van \& Gaillard, B. D. E., 1967. De zetmeelwaarde voor rundvee van voedervet en van ruwvoer. Veeteelt- en Zuivelber., $10: 536$.

Esplin, G., Hale, W. H., Hubbert, F. \& Taylor, B., 1963. Effect of animal tallow and hydrolyzed vegetable and animal fat on ration utilization and rumen volatile fatty acid production with fattening steers. J. Animal Sci., $22: 695$.

Francke, E. R., 1958. Der Einflusz reiner Nährstoffe auf die Verdaulichkeit der Futterrationen. Wiss. Abh. D.A.L., Berlin, 37.

Iwema, S., 1967. Wetenschap voor de praktijk. CLO-dagen, 26.

Jong, M. P. de, 1968. Algemeen advies over de zetmeelwaarde van vet. Wetenschap voor de praktijk.

Nehring, K., Schiemann, R. \& Hoffmann, L., 1966. Vorschlag eines neuen Systems der energetischen Bewertung des Futters auf der Grundlage der Netto-energie-Fett. Sitzungsberichte Bd. XV, Heft 21

Niesar, K. H., 1965. Besonderheiten des Fettstoffwechsels landwirtschaftlicher Nutztiere und Futterfetteinsatz. Zeitschr. Tierphysiol., Tierern. Futtermk., $20: 187$.

Nottle, M. C. \& Rook, J. A. F., 1963. The effect of dietary fat on the production of volatile fatty acids in the rumen of the cow. Proc, Nutr. Soc., 22: VII. 
Orth, A., Kaufmann, W. \& Rohr, K., 1966. Beitrag zur Frage des Einflusses höherer und verschiedenartiger Fettgaben auf die Leistung von Milchkühen und die Verdauungsvorgänge im Pansen. Zeitschr. Tierphysiol., Tierern. u, Futtermk., $21: 83$.

Page, H. M., Erwin, E. S. \& Roubicek, C. B., 1958. Influence of vitamin A deficiency and tallow on carotene utalization and digestibility of ration constituents. Proc. West. Sec. Am. Soc. Animal Prod., 9: XXIII.

Petterson, A., 1964. Inverkan av hög kalciumgiva på total-fettets och de enskilda fettsyrornas smältbarhet hos växande svin. Lantbrukshögskolans Medd., A 16: 1 .

Pfander, W. H. \& Verma, I. S., 1957. Physical factors that influence the response of sheep to added corn oil. J. Animal Sci., 16: 1087.

Schiemann, R., Nehring, K. \& Hoffmann, L., 1963. Die energetische Bewertung der Futterstoffe. 5. Mitt. Arch. Tierern. 13: 177.

Swift, R. W., Thacker, E. J., Black, A., Bratzler, J. W. \& James, W. H., 1947. Digestibility of rations for ruminants as affected by proportions of nutrients. J. Animal Sci., 6: 432.

Tillman, A. D. \& Brethour, J. R., 1958. The effect of corn oil upon the metabolism of calcium and phosphorus by sheep. J. Animal Sci, $17: 782$.

Ward, J. K., Tefft, C. W., Sirny, R. J., Edwards, H. N. \& Tillman, A. D., 1957. Further studies concerning the effect of alfalfa ash upon the utilization of low-quality roughages by ruminant animals. J. Animal Sci., 16: 633 .

White, T. W., Grainger, R. B., Baker, F. H. \& Stroud, J. W., 1958. Effect of supplemental fat on digestion and the ruminal calcium requirement of sheep. J. Animal Sci., 17: 797.

Wind, J., Deijs, W. B. \& Kemp, A., 1966. Hogere vetzuren in het voedsel en hun mogelijke rol bij het optreden van hypomagnesemie in de weide. Jaarb. IBS 1966: 91. 